\title{
BIRMINGHAM UNIVERSITY RADIOCARBON DATES VII
}

\author{
F. W. SHOTTON and R. E. G. WILLIAMS
}

The University of Birmingham, Birmingham, England

The following list of dates contains all measurements made during 1972, i.e., since our last list. Counting equipment, operating procedures and sample pretreatment are the same as previously described (R., 1969, v. 11, p. 263). Age calculations are based on $95 \%$ activity of the NBS oxalic acid standard computed from the Libby half-life of $5570 \pm 30 \mathrm{yr}$. Background samples are synthesized from Welsh anthracite. Errors quoted refer only to the standard deviation $\left(\mathrm{l}_{\sigma}\right)$ calculated from a statistical analysis of sample, background and standard count rates.

Previously $\mathrm{C}^{13} / \mathrm{C}^{12}$ ratios were not measured and the "normal" deviation of $-25.0 \%$ on the PDB scale was assumed for all samples. In this list where $\mathrm{C}^{13} / \mathrm{C}^{12}$ ratio measurements have been made $\delta \mathrm{C}^{13}$ values relative to the PDB standard (Craig, 1961) are listed together with the $\delta \mathrm{C}^{13}$ corrected ages. In all other cases we have assumed the "normal" deviation. $\delta \mathrm{C}^{13}$ values were measured on $\mathrm{CH}_{4}$ gas samples as parts per mil $(\%)$ observed deviation from our current NBS oxalic acid methane counting standard. After correction for zero enrichment, $\mathrm{H}_{2} \mathrm{O}$ and $\mathrm{CH}_{5}+$ contribution to the 17 peak, these values were converted to the PDB scale by making $\mathrm{C}^{13} / \mathrm{C}^{12}$ ratio measurements on $\mathrm{CO}_{2}$ prepared from NBS Solenhofen limestone relative to NBS oxalic acid $\mathrm{CO}_{2}$ and remeasuring the ratio in corresponding methane samples after conversion by ruthenium catalyst. We have observed differences in $\mathrm{C}^{13} / \mathrm{C}^{12}$ isotopic ratios ranging from 2 to $3 \%$ in converting from $\mathrm{CO}_{2}$ to $\mathrm{CH}_{4}$.

\section{ACKNOWLEDGMENTS}

Sample descriptions are from information provided by collectors and submitters. We particularly wish to thank A. S. Johnson for technical assistance in the Radiocarbon Dating Laboratory and L. Salvini for routine sample preparation and pretreatment.

\section{SAMPLE DESCRIPTIONS}

I. GEOLOGIC SAMPLES

\section{A. British Isles}

\section{County Fermanagh series, $N$ Ireland}

Vegetable debris, largely wood and moss, washed from sandy silt ca. $4.0 \mathrm{~m}$ thick and exposed $100 \mathrm{~m}$ across at depth ca. $10.0 \mathrm{~m}$ below highest point of drumlin at Hollymount, Co. Fermanagh, N Ireland (54 $18^{\prime} 30^{\prime \prime}$ N Lat, $7^{\circ} 27^{\prime} 00^{\prime \prime}$ W Long, Grid Ref. H3640). Coll. 1971 and subm. by G. F. Mitchell, Geol. Dept., Trinity College, Dublin. 
Birm-275.

$>\mathbf{3 6 , 8 5 0}$

Birm-309.

$>41,500$

$\delta \mathbf{C}^{14 \%} \%=-\mathbf{1 0 0 2 . 8 2} \pm \mathbf{1 . 4 3}$

General Comment: determinations indicate considerable age and inactivity as shown by $\delta \mathrm{C}^{14}$ suggests an Interglacial (McCabe, 1969). Contained flora supports this interpretation.

\section{Fylingdales Moor series, Yorkshire}

Wood and plant detritus from auger holes in overflow channels of former glacial lake at Fylingdales Moor, Yorkshire $\left(54^{\circ} 24^{\prime} 00^{\prime \prime} \mathrm{N}\right.$ Lat, $0^{\circ} 36^{\prime} 00^{\prime \prime} \mathrm{W}$ Long). Coll. 1971 and subm. by F. W. Shotton and R. R. Moore, Geol. Dept., Univ. Birmingham.

\section{Birm-295.}

$3780 \pm 350$

Plant detritus washed from peaty clay at 2.14 to $2.50 \mathrm{~m}$ depth, +196.84 to $196.48 \mathrm{~m}$ alt., in auger hole on $\mathrm{E}$ side of glacial lake (Grid Ref. NZ902017).

\section{Birm-296.}

$3900 \pm 500$

Plant detritus with small twigs (Betula) washed from peaty clay at 5.00 to $5.20 \mathrm{~m}$ depth, +193.98 to $193.78 \mathrm{~m}$ alt., in auger hole on $\mathrm{E}$ side of glacial lake (Grid Ref. NZ903018).

\section{Birm-297.}

$3650 \pm 200$

Plant material washed from detritus mud at 5.17 to $5.50 \mathrm{~m}$ depth, +193.81 to $+193.48 \mathrm{~m}$ alt., in auger hole on SE side of glacial lake (Grid Ref. NZ900017).

\section{Birm-315.}

Wood from base of peat bed at $1.0 \mathrm{~m}$ depth on $\mathrm{W}$ side of glacial lake (Grid Ref. NZ890001).

\section{Birm-316.}

$7070 \pm 130$

5120 B.C.

Wood from base of peaty soil at $0.80 \mathrm{~m}$ depth on $\mathrm{W}$ side of glacial lake (Grid Ref. NZ881013).

General Comment: samples chosen to study correlation between overflow channels on $\mathrm{E}$ and $\mathrm{W}$ sides of glacial lake in Cleveland Hills (Kendall, 1902).

\section{Birm-302. Morfa Nefyn, N Wales}

$$
\begin{gathered}
\text { (a) } 37,300 \quad+1630 \\
\text { 35,350 B.c. } \\
\text { (b) }>43,000
\end{gathered}
$$

Wood washed from organic debris from thick succession of fluvioglacial sand and gravel ca. $8 \mathrm{~m}$ thick overlying till, $25 \mathrm{~m} \mathrm{~W}$ of beach rd. 
from Morfa Nefyn, N Wales (52 $55^{\prime} 43^{\prime \prime}$ N Lat, $4^{\circ} 22^{\prime} 51^{\prime \prime}$ W Long, Grid Ref. SH283408). Coll. 1971 by D. Hopley; subm. by R. H. Johnson, Geog. Dept., Univ. Manchester. Comment: sample (a) after alkali pretreatment, (b) humate extract. Older date for (b) probably due to greatly humified wood. Most of sample dissolved in $\mathrm{NaOH}$; insoluble residue may have contained undetected modern rootlets or intrusive animal remains. Sample must be derived and dating of deposit difficult but likely that fluvioglacial sand late Devensian (Whittow and Ball, 1970; Synge, 1970; Saunders, 1968).

\section{Tattershall Castle pit series, Lincolnshire}

Plant debris washed from bed of detritus mud interbedded in gravel 1.22m above Ipswichian deposit (Birm-260: $>42,000$; R., 1973, v. 15, p. 4) and ca. $0.50 \mathrm{~m}$ above horizon with organic silt containing an arctic/alpine insect assemblage at Tattershall Castle gravel pit, Lincolnshire $\left(53^{\circ} 05^{\prime} \mathrm{N}\right.$ Lat, $0^{\circ}$ 12' W Long, Grid Ref. TF210570). Coll. 1971 and subm. by G. R. Coope and M. A. Girling, Geol. Dept., Univ. Birmingham.

\section{Birm-308.}

Preliminary small sample.

\section{Birm-341.}

Larger sample.

41,050 B.C.

General Comment (G.R.C.): dates temperate assemblage of insects and mollusks assoc. with apparently treeless landscape.

\section{Lea Marston pit series, Warwickshire}

Wood fragments washed from brown clayey peat overlying gravel ca. $2.5 \mathrm{~m}$ thick which overlies Keuper Marl at Lea Marston pit, Coton, Warwickshire (52० $32^{\prime} 40^{\prime \prime}$ N Lat, $1^{\circ} 41^{\prime}$ 20" W Long, Grid Ref. SO212942). Coll. 1970 and subm. by P. J. Osborne, Geol. Dept., Univ. Birmingham.

Birm-329.

$9420 \pm 90$

7470 B.C.

$\delta C^{13}=-26.9 \%$

Sample from ca. $5 \mathrm{~cm}$ band at 2.46 to $2.51 \mathrm{~m}$ depth. Comment: cf. Birm-252: $9700 \pm 130$; R., 1973, v. 15, p. 3, separate sample from same horizon.

\section{Birm-310.}

Sample from ca. $5 \mathrm{~cm}$ band at 2.51 to $2.56 \mathrm{~m}$ depth.

Birm-311.

Sample from ca. $6 \mathrm{~cm}$ band at 2.56 to $2.62 \mathrm{~m}$ depth.
$9450 \pm 200$

7500 B.C.

$\delta C^{13}=-25.9 \%$

$9420 \pm 200$

7470 B.C. 
Birm-312.

(a) $9530 \pm 200$

$\mathbf{7 5 8 0 ~ \mathrm { B.C. }}$

$\delta C^{13}=-26.2 \%$ o

(b) $9270 \pm 200$ 7320 B.c.

$\delta C^{13}=-26.2 \%$

Sample from ca. $5 \mathrm{~cm}$ band at 2.67 to $2.72 \mathrm{~m}$ depth. Comment: (a) and (b) are same gas sample measured at different counter filling pressures. Cf. Birm-215: $9510 \pm 235$; R., 1971, v. 13, p. 146 from ca. $2.74 \mathrm{~m}$ depth. General Comment (P.J.O.): only Salix and Betula tree pollen commonly present but all samples contain thermophilous insect faunas suggesting summer temperatures capable of allowing growth of deciduous forest.

\section{Roos Bog series, E Riding, Yorkshire}

Samples of fine detritus coll. by multiple shots with "Russian" peat sampler at the Bog, Roos, Yorkshire $\left(53^{\circ} 44^{\prime} \mathrm{N}\right.$ Lat, $0^{\circ} 05^{\prime \prime} \mathrm{W}$ Long, Grid Ref. TA274288). Coll. 1971 and subm. by J. R. Flenley and S. C. Beckett, Geog. Dept., Univ. Hull.

\section{Birm-317.}

$13,050 \pm 270$

Sample from 11.33 to $11.40 \mathrm{~m}$ depth.

\section{1,100 в.c.}

\section{Birm-318.}

$11,500 \pm 170$

Sample from 11.10 to $11.15 \mathrm{~m}$ depth.

General Comment: insufficient sample for alkali pretreatment. Sample bands separated by $0.18 \mathrm{~m}$ clay. Dates suggest Pollen Zones I and II.

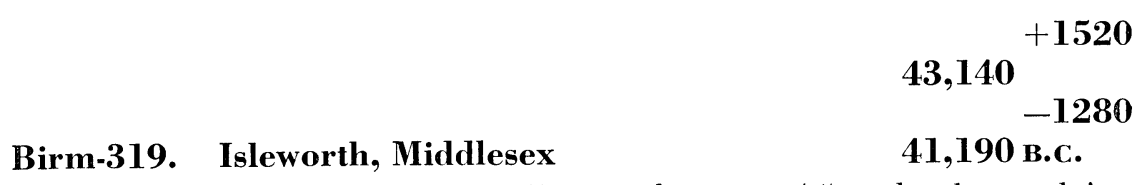

Plant debris washed from silty mud at ca. $4.5 \mathrm{~m}$ depth overlying London Clay at Willmets pit, Isleworth, Middlesex $\left(51^{\circ} 27^{\prime} \mathrm{N}\right.$ Lat, $0^{\circ} 20^{\prime \prime}$ W Long, Grid Ref. TQ157746). Coll. 1963 and subm. by G. R. Coope. Comment (G.R.C.): sample contains thermophilous insect assemblage assoc. with interstadial type stratigraphy.

\section{Loughnahanagen series, County Wicklow, Ireland}

Organic material from erratic balls derived from lake deposits pushed into 2 of 12 push-moraine ridges on floor of drained cirque lake at Loughnahanagen, Co. Wicklow, Ireland $\left(53^{\circ} 01^{\prime} 30^{\prime \prime} \mathrm{N}\right.$ Lat, $6^{\circ} 24^{\prime} 30^{\prime \prime}$ W Long, Grid Ref. T 080988). Coll. 1971 and subm. by E. A. Colhoun, Geog. Dept., Trinity College, Dublin. 


\section{Birm-320.}

$11,500 \pm 550$

9550 в.c. corrie.

Sample from ca. $1.5 \mathrm{~m}$ below surface of moraine ridge on $\mathrm{S}$ side of

\section{Birm-321.}

$$
11,600 \pm 260
$$

9650 B.C. corrie.

Sample from ca. $1.5 \mathrm{~m}$ below surface of moraine ridge on $\mathrm{N}$ side of General Comment: samples too small for alkali pretreatment. Dates agree and confirm expected Zone II (Aller $\phi$ d) age of organic material and that later cirque glaciation likely to be Zone III.

\section{Birm-323. S Carse Borehole, Kirkcudbrightshire, $\quad 9390 \pm 130$ Scotland \\ 7440 B.C.}

Peaty silt from 10.21 to $10.36 \mathrm{~m}$ depth, -0.98 to $-1.13 \mathrm{~m}$ alt., in borehole in carse deposit in basin within fluvio-glacial material at Carsethorn, Kirkcudbrightshire, Scotland ( $54^{\circ} 55^{\prime} \mathrm{N}$ Lat, $3^{\circ} 35^{\prime} \mathrm{W}$ Long, Grid Ref. NX98835944). Coll. 1970 and subm. by W. G. Jardine, Geol. Dept., Univ. Glasgow. Comment (W.G.J.): sample overlies sand with shells $1.07 \mathrm{~m}$ thick which overlies Red Clay. Date approximates transgression in area to beginning of Flandrian.

\section{Birm-324. Midtown Borehole, Dumfriesshire, $\quad 6470 \pm 280$ Scotland \\ 4520 B.C.}

Peat from 0.60 to $0.70 \mathrm{~m}$ depth, +8.63 to $+8.73 \mathrm{~m}$ alt., in borehole in carse deposit overlying fluvio-glacial gravel at Midtown, Dumfriesshire, Scotland (54 $58^{\prime} \mathrm{N}$ Lat, 3 22' W Long, Grid Ref. NY11896577). Coll. 1968 and subm. by W. G. J. Comment: cf. Q-638: $6645 \pm 120$ (R., 1962, v. 4 , p. 59) from similar site in Dumfriesshire.

$$
7400 \pm 150
$$

Birm-325. Newbie Cottages, Dumfriesshire, Scotland $\mathbf{5 4 5 0}$ B.c.

Organic detritus underlying carse deposit at +5.50 to $+5.60 \mathrm{~m}$ alt. and overlying fluvio-glacial gravel $380 \mathrm{~m} \mathrm{NW}$ of Newbie Cottages, Dumfriesshire, Scotland (54 $58^{\prime} \mathrm{N}$ Lat, $3^{\circ} 18^{\prime} \mathrm{W}$ Long, Grid Ref. NY16446515). Coll. 1971 and subm. by W. G. J. Comment: Birm-222: $7540 \pm 150$ (R., 1971 , v. 13, p. 145) from stratigraphically similar site.

\section{Oronsay Midden series, Inner Heb̆rides, Argyllshire, Scotland}

Shell (Patella vulgata) and wood charcoal (Ouercus, Alnus, Ulmus, and Pinus) id. by R. Jones, Univ. Sheffield, from shell midden deposit ca. $0.60 \mathrm{~m}$ thick overlain by $1.0 \mathrm{~m}$ wind-blown sand on SE coast of I. of Oronsay in Inner Hebrides, Argyllshire, Scotland $\left(56^{\circ} 01^{\prime} \mathrm{N}\right.$ Lat, $6^{\circ} 14^{\prime} \mathrm{W}$ Long, Grid Ref. NR359880). Coll. and subm. by P. A. Mellars, Ancient Hist. Dept., Univ. Sheffield. 


\section{Birm-346. \\ Birm 346.}
(a) $5150 \pm 380$
3200 B.C.
$\delta C^{13}=-21.0 \%$

(b) $4920 \pm 400$ 2970 B.C.

$\delta C^{13}=-20.5 \%$

Wood charcoal from 1.20 to $1.30 \mathrm{~m}$ depth in upper half of shell midden very close to center of midden. Sample (a) after alkali pretreatment, (b) humate extract. Comment: stratigraphically younger than Birm347 and -348 both $0.225 \mathrm{~m}$ below Birm- 346 .

\section{Birm-347.}

$5450 \pm 140$

Wood charcoal from bottom of shell midden, 1.45 to $1.50 \mathrm{~m}$ depth, vertically below Birm-346.

\section{Birm-348.}

$$
\begin{gathered}
\text { (a) } \mathbf{5 8 5 0} \pm \mathbf{3 1 0} \\
\mathbf{3 9 0 0} \text { в.C. } \\
\delta C^{13}=-1.5 \% \\
\text { (b) } \mathbf{5 7 2 0} \pm \mathbf{1 4 0} \\
\mathbf{3 7 7 0} \text { в.C. } \\
\delta C^{13}=-0.8 \% \\
\text { (c) } \mathbf{5 5 7 0} \pm \mathbf{1 4 0} \\
\mathbf{3 6 2 0} \text { в.c. } \\
\delta C^{13}=-1.8 \%
\end{gathered}
$$

Inner (a), middle (b), and outer (c) fraction of shells (Patella vulgata) from same position as Birm-347. Comment: shells are refuse of food originally coll. in living state. Birm- 347 not corrected for $\delta \mathrm{C}^{13}$, but compared with Birm-346, probably is 60 to $70 \mathrm{yr}$ older than determined. Dates of assoc. limpets coll. for food apparently ca. $300 \mathrm{yr}$ older, which may be extent of hard-water error. Cf. age of midden shells and bone from another Oronsay site, Cnoc Sligeach, GX-1903: $5015 \pm 210$ and GX-1904: $5755 \pm 180$ (Mackie, 1971).

\section{Oronsay beach series, Inner Hebrides, Argyllshire, Scotland}

Shells from emerged beach gravel adjacent to Mesolithic shell middens (Mellars and Payne, 1971) at Oronsay, Argyllshire, Scotland. Coll. 1971 and subm. by W. G. J.

\section{Birm-326.}

$$
\begin{gathered}
\text { (a) } 7170 \pm 150 \\
5220 \text { B.c. } \\
\text { (b) } 6850 \pm 120 \\
4900 \text { B.c. } \\
\text { (c) } 6800 \pm 200 \\
4850 \text { B.c. }
\end{gathered}
$$

Inner (a), middle (b), and outer (c) fraction of bivalve shells (mainly Patella) from $400 \mathrm{~m} \mathrm{~N}$ of Seal Cottage, Oronsay, Argyllshire, Scotland 
$\left(56^{\circ} 00^{\prime} \mathrm{N}\right.$ Lat, $6^{\circ} 14^{\prime} \mathrm{W}$ Long, Grid Ref. NR361885). Comment: $\delta \mathrm{C}^{13}$ not measured, but Birm-348 and -363 indicate that results should be ca. 400 yr greater than given.

(a) $7020 \pm 140$ 5070 B.C.

$\delta C^{13}=+3.8 \%$

\section{Birm-363.}

(b) $6870 \pm 130$ 4920 B.C.

$\delta C^{13}=+0.8 \%$

Inner (a) and outer (b) fraction of bivalve shells (Arctica islandica) in emerged beach $70 \mathrm{~m} \mathrm{SE}$ of unexcavated shell midden Caisteal-nan-Gillean, Oronsay (56 $06^{\prime} \mathrm{N}$ Lat, $6^{\circ} 14^{\prime} \mathrm{W}$ Long, Grid Ref. NR359878).

(a) $7420 \pm 110$ $\mathbf{5 4 7 0}$ B.C. $\delta C^{13}=+0.8 \%$

Birm-364.

(b) $7060 \pm 150$ 5110 в.C.

$\delta C^{13}=+0.9 \%$

Inner (a) and outer (b) fraction of bivalve shells (Arctica islandica) $135 \mathrm{~m} \mathrm{~N}$ of shell midden Cnoc Sligeach, Oronsay $\left(56^{\circ} 01^{\prime} \mathrm{N}\right.$ Lat, $6^{\circ} 12^{\prime} \mathrm{W}$ Long, Grid Ref. NR373891).

General Comment: oldest date for food shells on beach, $5850 \pm 310$. Youngest date for shells forming raised beach, $7020 \pm 140$. Fall in sea level caused beach to emerge within this interval.

\section{Thorne Waste series, Yorkshire}

Wood washed from peat overlying clayey silt at Thorne Waste, Yorkshire (53 $37^{\prime} 30^{\prime \prime} \mathrm{N}$ Lat, $0^{\circ} 55^{\prime} 10^{\prime \prime} \mathrm{W}$ Long). Coll. 1972 and subm. by $\mathrm{P}$. C. Buckland, Geol. Dept., Univ. Birmingham.

\section{Birm-335.}

$3260 \pm 100$

Wood (Betula) from base of peat bed ca. $0.5 \mathrm{~m}$ thick at 1.0 to $1.5 \mathrm{~m}$ depth at Thorne Waste, Yorkshire (Grid Ref. SE728152).

\section{Birm-336.}

$3130 \pm 90$

1180 B.c.

$$
\delta C^{13}=-21.8 \%
$$

Burnt wood (Pinus) from base of peat bed ca. $0.6 \mathrm{~m}$ thick at 1.0 to $1.6 \mathrm{~m}$ depth at Thorne Waste, Yorkshire (Grid Ref. SE729154).

General Comment (P.C.B.): dates mark phase of widespread freshwater flooding in Humber basin. Later date from tree burnt in Landnam phase of Late Bronze age assoc. with timber trackway (Birm-358, below). More than 8 species of mature forest insects (Urwaldtier), no longer recorded in Britain, were found here; their disappearance is perhaps directly related to forest clearance. 
Wood (Alnus) from base of peat bed at +3.6 to $+3.9 \mathrm{~m}$ alt. underlying blue-gray clay in cliff sec. at West Angle Bay, Pembrokeshire $\left(51^{\circ} 41^{\prime}\right.$ N Lat, $5^{\circ} 06^{\prime}$ W Long, Grid Ref. SM853031). Coll. 1970 by D. P. Kaill and A. Clowes; subm. by D. Q. Bowen, Geog. Dept., Univ. Aberystwyth. Comment: date supports Ipswichian age for sample and precludes possibility of Flandrian age.

Birm-333. Queensford, Oxfordshire

Plant debris, mainly terrestrial, washed from silty mud at ca. $3.0 \mathrm{~m}$ depth in side of gravel pit at Queensford, near Dorchester, Oxfordshire (51 ${ }^{\circ} 39^{\prime} \mathrm{N}$ Lat, $0^{\circ} 09^{\prime} \mathrm{W}$ Long, Grid Ref. SU582952). Coll. 1971 and subm. by G. R. C. Comment (G.R.C.): dates rich assemblage of insects indicating a cold continental climatic regime.

\section{Birm-334. Standlake Common, Oxfordshire}

$29,500 \pm 300$

Twigs washed from silty mud overlain by ca. $4.0 \mathrm{~m}$ gravel and directly overlying Jurassic clay floor of pit at Standlake Common, Oxfordshire (51 ${ }^{\circ} 43^{\prime}$ N Lat, $0^{\circ} 26^{\prime}$ W Long, Grid Ref. SP395020). Coll. 1971 and subm. by G. R. C. Comment (G.R.G.): date is maximum for aggregation of terrace gravel and dates assoc. arctic insect fauna.

\section{Birm-340. Caldey Island, off Tenby, $\mathbf{S}$ Wales}

$22,350 \pm 620$

Collagen from scapula of rhinoceros (Tichorhinus) id. by J. A. Bateman, Natl. Mus. Wales ca. $3.7 \mathrm{~m}$ deep in unstratified limestone rubble filling fissure beneath similar rubble on floor of cave at Ogof-yr-Ychen on inaccessible cliff ledge, ca. $+13.7 \mathrm{~m}$ alt., on NE coast of Caldey I., off Tenby, Pembrokeshire (513 $38^{\prime} 15^{\prime \prime}$ N Lat, $4^{\circ} 40^{\prime} 46^{\prime \prime}$ W Long, Grid Ref. SS147968). Coll. 1971 and subm. by Brother Van Nedervelde, Caldey Abbey, Pembrokeshire. Comment: date consistent with other "cold" fauna of Late Devensian period. C.. Birm-146: 18,000 +1400 (R., 1971, v. 13, p. 141). An adinole blade of Magdalenian type occurred $0.5 \mathrm{~m}$ above dated bone.

\section{Birm-349. Messingham, Lincolnshire}

$$
\begin{gathered}
10,250 \pm 120 \\
8300 \text { в.C. } \\
\delta C^{13}=-27.4 \%
\end{gathered}
$$

Top of felted peat bed ca. $0.15 \mathrm{~m}$ thick at ca. $3.0 \mathrm{~m}$ depth overlying chalky Jurassic Boulder Clay at Messingham sand pit $0.40 \mathrm{~km} \mathrm{SW}$ of Belle Vue Farm, Lincolnshire (53 $31^{\prime} 50^{\prime \prime} \mathrm{N}$ Lat, $0^{\circ} 36^{\prime} 40^{\prime \prime}$ W Long, Grid Ref. SE913038). Coll. 1972 and subm. by P. C. Buckland. Comment (P.C.B.): date implies that cover sands were not deposited in this area until near 
end of Zone III. Sample yielded cold insect fauna, indicating high arctic conditions. Flint end-scraper found in deposit.

\section{Birm-350. Docking Common, NW Norfolk}

$19,300 \pm 300$ 17,350 в.c.

Buried soil overlain by ca. $3.0 \mathrm{~m}$ strongly involuted flint gravel and underlain by at least $5.0 \mathrm{~m}$ similar gravel on floor of shallow dry valley at

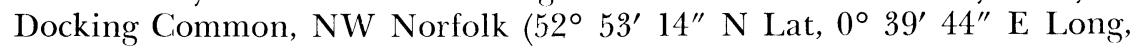
Grid Ref. TF791356). Coll. 1971 and subm. by A. Straw, Geog. Dept., Univ. Exeter. Comment (A.S.): sample separates comparable deposits of cryoturbated soliflual flint gravel and dates an interstadial prior to Holderness advance of Devensian ice, probably contemporaneous with deposition of upper gravel. Lower gravel also thought to be Devensian and tentatively correlated with Hunstanton advance.

\section{Birm-345. Grimston Hall, E Yorkshire}

$11,260 \pm 100$ 9310 B.c.

Plant debris including wood fragments with scales and seeds (Betula) washed from black sapropelic clay with assoc. bones (Perca fluviatilis). Sample from lower $10 \mathrm{~cm}$ of clay $20 \mathrm{~cm}$ thick overlying compressed peat and underlying laminated silts in coastal cliff sec. $21 \mathrm{~km}$ ENE of Hull at

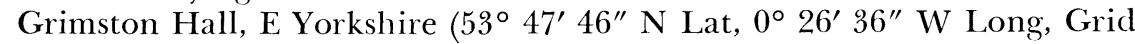
Ref. TA289352). Coll. 1972 and subm. by F. W. S. Comment (F.W.S.): compare dates from underlying peat, Birm-301: 11,250 \pm 170 and Birm298: $12,230 \pm 120$ (R., 1973, v. 15, p. 5). First datable deposits above Upper Devensian till are confirmed as Aller $\phi \mathrm{d}$.

Birm-361. Oban, Argyllshire, Scotland
(a) $11,770 \pm 230$ 9820 в.C. $\delta C^{13}=+1.2 \%$

(b) $12,190 \pm 240$ 10,240 B.C. $\delta C^{13}=-0.5 \%$

(c) $11,270 \pm 200$ 9320 в.C. $\delta C^{13}=-0.2 \%$

Inner (a), middle (b), and outer (c) fraction of barnacle plates (Balanus balanus), id. by S. Smith, attached to rock face at $+20.0 \mathrm{~m}$ alt. in Glen Crutten Quarry, Oban, Argyllshire, Scotland $\left(56^{\circ} 25^{\prime}\right.$ N Lat, $5^{\circ} 28^{\prime}$ W Long, Grid Ref. NM868299). Coll. 1971 and subm. by J. M. Gray, Geog. Dept., Univ. Edinburgh. Comment: percolating ground water running down rock face from overlying drift could account for some isotopic replacement. Dates indicate early Zone II, neglecting correction for hard water effect. Balanus balanus mainly lives now between high and low neap tides; thus, height of attachment $(+20.0 \mathrm{~m}$ alt.) could approximate mean sea level at that time. 
(a) $>36,900$

(b) $>32,900$

(c) $+850$

Birm-362. Stranraer, Wigtownshire, Scotland 28,940

Inner (a), middle (b), and outer (c) fraction of shells (Littorina littorea, Nassarius incrassatus, Trophonopsis clathratus, Mytilus edulis, Chlamys sp., Arctica islandica, Spisula sp., Nucula sp., Nuculana pernula, Astarte sp., Colus sp.), id. by S. Smith, from ca. $7.0 \mathrm{~m}$ depth in sand and gravel at Big Aird Sandpit, Stranraer, Wigtownshire, Scotland (54 $54^{\prime}$ N Lat, $4^{\circ} 58^{\prime}$ W Long, Grid Ref. NX098602). Coll. 1971 by D. G. Sutherland; subm. by J. M. G. Comment: sand forms part of Charlesworth's "Stranraer-Lammermuir Moraine" (Charlesworth, 1926), correlated by Sissons with the "Perth Readvance" limit (Sissons, 1963, 1964). Although shells are from floor of Irish Sea and are also affected by isotopic fractionation, dates support earlier age for last major glaciation of Scotland, probably early in Late Devensian.

\section{Hoxnian Interglacial series, Suffolk}

Wood from Trial XXIII of Singer and Wymer's current archaeologic excavations at Oakley Park pit, Hoxne, Suffolk $\left(52^{\circ} 20^{\prime} 45^{\prime \prime} \mathrm{N}\right.$ Lat, $1^{\circ} 11^{\prime}$ 50" E Long, Grid Ref. TM177766). Coll. 1972 and subm. by C. Turner, Dept. Botany, Univ. Cambridge.

Birm-365.

$$
\delta \mathrm{C}^{14}=-\mathbf{9 9 9 . 3 1} \pm \mathbf{0 . 6 8} \% \text { o }
$$

Trunk (Alnus), $4.2 \mathrm{~m}$ below surface, in wood peat of Stratum D (West, 1956).

Birm-387.

$$
\delta \mathbf{C}^{14}=-\mathbf{1 0 0 0 . 5 6} \pm \mathbf{0 . 5 9} \%
$$
surface.

Twigs and bark (mainly Betula) washed from wood peat, $4.5 \mathrm{~m}$ below

General Comment (F.W.S.): Hoxnian interglacial has long been accepted as beyond reach of $\mathrm{C}^{14}$ dating. Page (1972) claimed age of ca. 24,000, requiring proof that uncontaminated samples were not datable.

\section{Cledlyn Pingo series, mid-Cardiganshire}

Organic mud (gyttja) passing up into peat and overlying $>7.0 \mathrm{~m}$ of gray clayey silt filling pingo basin at Cledlyn, $12 \mathrm{~km}$ W of Lampeter, Cardiganshire (52 $05^{\prime} 25^{\prime \prime}$ N Lat, $4^{\circ} 14^{\prime} 20^{\prime \prime}$ W Long, Grid Ref. SN467477). Coll. 1972 and subm. by E. Watson, Geog. Dept., Univ. Aberystwyth. 
Birm-367.

$9020 \pm 400$

7070 B.C.

Russian auger peat $\left(\mathrm{W}_{1 \mathrm{a}}\right)$ from $2.745 \mathrm{~m}$ to $2.795 \mathrm{~m}$ below surface at center of Pingo W (Watson, 1972).

Birm-369.

$8910 \pm 290$

6960 B.C.

$\delta C^{13}=-25.6 \%$

Peat $\left(\mathrm{W}_{2 \mathrm{a}}\right.$ ) from 2.870 to $2.920 \mathrm{~m}$ below surface of bog in Pingo $\mathrm{W}$, close to Auger Hole $\mathrm{W}_{1}$.

\section{Birm-368.}

$9380 \pm 340$

7430 B.C.

$\delta C^{13}=-24.1 \%$

Combined sample: organic silt from 2.900 to $2.950 \mathrm{~m}$ depth in Auger Hole $W_{1}$, and from 3.025 to $3.075 \mathrm{~m}$ from Auger Hole $W_{2}$.

General Comment: deviations large because of small sample size. Initial thick silt filling after collapse of pingo antedates Pollen Zones IV and V.

\section{Birm-378. St. Bees, Cumberland}

$12,560 \pm 170$

10,610 в.c.

$\delta C^{13}=-26.4 \%$

Sticks washed from bottom $5 \mathrm{~cm}$ detritus mud overlying gray and red sand at St. Bees, Cumberland (54 29' N Lat, $3^{\circ} 36^{\prime}$ W Long, Grid Ref. NX965115). Coll. 1972 and subm. by G. R. C. Comment (G.R.C.): dates beginning of detritus mud and contained thermophilous insect assemblage (Pearson, 1962) similar to that in S England today.

\section{Birm-379. Sale, Cheshire}

$$
\begin{gathered}
3940 \pm 120 \\
1990 \text { B.C. } \\
\delta C^{13}=-26.3 \%
\end{gathered}
$$

Wood bark (Pinus) from $\log$ in bottom $2.0 \mathrm{~m}$ gravel, ca. $5.0 \mathrm{~m}$ thick, underlying ca. $4.0 \mathrm{~m}$ alluvium at Sale Ees, Cheshire $\left(53^{\circ} 25^{\prime} 45^{\prime \prime} \mathrm{N}\right.$ Lat, $2^{\circ} 17^{\prime} 45^{\prime \prime}$ W Long, Grid Ref. SJ801928). Coll. 1972 and subm. by P. J. O. Comment (P.J.O.): stratigraphy suggests either Ipswichian or postglacial. Preservation of contained insect fauna indicative of latter; confirmed by date.

\section{Azores series}

\section{B. Miscellaneous Geologic Samples}

Carbonized wood from tuff, ignimbrite, and pumice in the Azores. Coll. 1970 and subm. by G. P. L. Walker, Geol. Dept., Imperial College, London.

(a) $1020 \pm 100$ A.D. 930

$\delta C^{13}=-22.9 \%$

Birm-305.

(b) $1070 \pm 100$ A.D. 880

$\delta C^{13}=-22.9 \%$ 


\section{Birm-330.}

Carbonized wood from uppermost palagonite tuff horizon on side of Espalamaca, $1 \mathrm{~km}$ NE of center of Horta, Fial, Azores $\left(38^{\circ} 32^{\prime} \mathrm{N}\right.$ Lat, $28^{\circ} 37^{\prime} \mathrm{W}$ Long). Comment: (a) and (b) are separate determinations on same gas. Birm-330 is separate sample from same piece of carbonized wood. Sample originally believed older than Birm-126: $1200 \pm 70$ (R., 1970 , v. 12, p. 393), from youngest pumice bed caused by main volcano on Fial I. but dates show sample to be much younger than expected.

Birm-306.

$23,100 \pm 350$

Part of large branch or trunk of carbonized wood from $3 \mathrm{~m}$ above base of Lajes ignimbrite from quarry beside main rd. $2 \mathrm{~km} \mathrm{E}$ of Angra do Hervismo, Terceira, Azores (38 $39^{\prime} \mathrm{N}$ Lat, $27^{\circ} 12^{\prime} \mathrm{W}$ Long). Comment: dates critical horizon in tephrochronologic study of Terceira $I$.

\section{Birm-307.}

(a) $>34,200$

Part of carbonized tree from cliff $\mathrm{sec} .80 \mathrm{~m}$ high consisting of 67 separate beds of ash or pumice caused by volcanic eruptions of Agua de Pau. Sample from $18 \mathrm{~m}$ up, i.e., 15th deposit from base in coastal cliff midway between Ribeira Cha and Ponta da Piramide on S coast of São Miguel I. W of Villa Franca $\left(37^{\circ} 43^{\prime} 00^{\prime \prime} \mathrm{N}\right.$ Lat, $25^{\circ} 28^{\prime} 30^{\prime \prime} \mathrm{W}$ Long). Comment: stratigraphically much older than previous radiocarbon dates from São Miguel, Birm-35: $4672 \pm 100$ (R., 1968, v. 10, p. 204); Birm-90: $4435 \pm 99$, Birm-91: $5990 \pm 110$ (R., 1969, v. 11, p. 266); Birm-125: $3240 \pm$ 90 (R., 1970, v. 12, p. 392).

\section{Birm-322. Ratyezów, Lublin, Poland}

39,550 в.c.

Humus (Chernozem) from 7.8 to $7.9 \mathrm{~m}$ depth in loess sequence of $14.6 \mathrm{~m}$ at Ratyczów, Lublin Plateau, Poland (50 $30^{\prime} 00^{\prime \prime} \mathrm{N}$ Lat, $23^{\circ} 43^{\prime} 30^{\prime \prime}$ E Long). Coll. 1971 and subm. by J. Buraczyński, Geog. Inst., Univ. CurieSkłodowska, Lublin, Poland. Comment: date corresponds with climatic optimum of Upton Warren interstadial (Mid-Devensian) in Britain.

\section{Bфlling Sф series, Denmark}

Samples from trench in sand with intercalated peats, cut in marginal sediments of Late Weichselian lake deposits at $\mathrm{B} \phi \mathrm{lling} \mathrm{S} \phi$, Jutland $\left(56^{\circ}\right.$ $10^{\prime} \mathrm{N}$ Lat, $9^{\circ} 00^{\prime} \mathrm{E}$ Long). Distances along trench of sample colln. points are referred to same datum used previously by the late J. Iversen. Coll. 1971 and subm. by F. W. S.

\section{Birm-353.}

$$
\begin{gathered}
10,400 \pm 260 \\
8450 \text { B.c. } \\
\delta C^{13}=-25.6 \%
\end{gathered}
$$

At $32.8 \mathrm{~m}$. Peat (lowest of 3 assoc. bands) 1.45 to $1.49 \mathrm{~m}$ below surface. 


\section{Birm 357.}

$10,340 \pm 240$

8390 B.C.

$\delta C^{13}=-23.6 \%$

At $9.0 \mathrm{~m}$. Washed vegetation, mainly moss, from peat from 0.80 to $0.85 \mathrm{~m}$ below surface.

Birm-356.

$$
\begin{gathered}
10,890 \pm 250 \\
8940 \text { в.C. }
\end{gathered}
$$$$
\delta C^{13}=-24.3 \%
$$

At $9.0 \mathrm{~m}$. Washed plant material from black sandy peat, 1.00 to $1.05 \mathrm{~m}$ below surface.

\section{Birm-355.}

$$
\begin{gathered}
11,000 \pm 250 \\
9050 \text { в.C. } \\
\delta C^{13}=-25.8_{/ c 0}^{\prime \prime c}
\end{gathered}
$$

At $9.0 \mathrm{~m}$. Washed plant material, mainly moss, from brown felted peat, 1.25 to $1.32 \mathrm{~m}$ below surface.

Birm-354.

$$
\begin{aligned}
& 11,610 \pm 260 \\
& 9660 \text { в.C. } \\
& \delta C^{13}=-24.9 \%
\end{aligned}
$$
surface.

At $9.0 \mathrm{~m}$. Washed plant from black sandy peat, 1.49 to $1.53 \mathrm{~m}$ below

General Comment (F.W.S.): dates form consistent series, suggesting succession from early Zone II (Aller $\phi$ d) to late Zone III (Younger Dryas), but no proved Zone I (Older Dryas, B $\phi l l i n g$, Oldest Dryas) (Anderson et al., 1953).

\section{Maktak Fjord series, Baffin Island}

Peat from top and base of bed $1.07 \mathrm{~m}$ thick in terminal moraine of

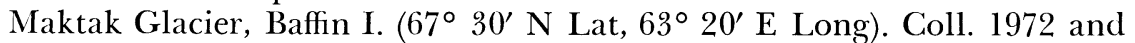
subm. by G. S. Boulton, Dept. Environmental Sci., Univ. Norwich.

\section{Birm-370.}

Top $5 \mathrm{~cm}$ of peat bed.

\section{Birm-380.}

Bottom $12 \mathrm{~cm}$ of peat bed.
$1480 \pm 160$ A.D. 470

$$
\delta C^{13}=-21.7 \%
$$

$$
2500 \pm 170
$$

550 B.C.

$\delta C^{13}=-24.8 \%$

General Comment: dates time when site was unoccupied by ice.

II. ARCHAEOLOGIC SAMPLES

\section{A. British Isles}

\section{Chapel Brampton series, Northamptonshire}

Charcoal from flat cremation cemetery $\mathrm{N}$ of Chapel Brampton village, Northamptonshire $\left(52^{\circ} 17^{\prime} 29^{\prime \prime}\right.$ N Lat, $0^{\circ} 56^{\prime} 26^{\prime \prime} \mathrm{W}$ Long, Grid Ref. 
SP722664). Coll. 1970 and subm. by W. R. G. Moore, Central Mus., Northampton.

Birm-313.

$3060 \pm 120$

Sample from shallow pit, 0.36 to $0.56 \mathrm{~m}$ depth, containing several sherds of bucket-urn pottery.

Birm-314.

$3250 \pm 100$

Sample from 2nd pit, 0.36 to $0.81 \mathrm{~m}$ depth, containing much charcoal. General Comment: similar cremations buried in plain bucket-urns in S England, particularly Dorset, Wiltshire, and Sussex (Deverel-Rimbury culture). Confirms this site also as Middle Bronze age. Older than other Midland cemeteries, e.g., Birm-26, $2701 \pm 41$ (R., 1968, v. 10, p. 204), Birm-62, $2712 \pm 75$ (R., 1969, v. 11, p. 268).

\section{Birm-328. Misterton Carr, Nottingham}

(a) $4330 \pm 100$ 2380 B.C.

(b) $4200 \pm 120$ 2250 в.c.

Twigs washed from base of fibrous peat bed at ca. $2.0 \mathrm{~m}$ depth in former channel of R. Idle at Misterton Carr, Nottinghamshire $\left(53^{\circ} 26^{\prime} 50^{\prime \prime}\right.$ N Lat, $0^{\circ} 55^{\prime} 35^{\prime \prime}$ W Long, Grid Ref. SK 728950). Coll. 1971 and subm. by P. C. B. Comment (P.C.B.): (a) and (b) are separate determinations on different samples from same horizon. Sample from immediately below sandy horizon in peat, a result of localized clearance in Late Neolithic/ Early Bronze age. First site of this period in E Midlands to be dated.

\section{Ees Gravel pit series, Radcliffe, Lancashire}

Wood, twigs, and bark assoc. with structure of vertical wooden stakes and interlaced branches from layer ca. $1.0 \mathrm{~m}$ thick of stratified silt, sand, and organic debris underlying ca. $2.0 \mathrm{~m}$ alluvial silt and overlying gravel on flood plain of R. Irwell $1.21 \mathrm{~km}$ upstream from Radcliffe, Lancashire (53 $33^{\prime}$ N Lat, $2^{\circ} 19^{\prime}$ W Long, Grid Ref. SD797071). Coll. 1961 by J. S. Hallam; subm. by S. Limbrey, Ancient Monuments Lab., Dept. Environment, London.

Birm-338.

Wood (Quercus) part of vertical stake for a timber structure. (a) and 
Birm-339.

$$
\begin{array}{r}
240 \pm 120 \\
\text { A.D. } 1710 \\
\delta C^{13}=-23.9 \%
\end{array}
$$

Wood (Betula), twigs, and bark from 2nd layer containing stakes and interlaced branches.

General Comment: samples clearly modern or nearly so, despite thickness of alluvial cover.

\section{Broxbourne series, Hertfordshire}

Wood (? Pinus) from below Mesolithic site at Broxbourne, Hertfordshire (51 ${ }^{\circ} 45^{\prime} 25^{\prime \prime} \mathrm{N}$ Lat, $0^{\circ} 00^{\prime} 30^{\prime \prime}$ E Long, Grid Ref. TL379082). Coll. 1972 and subm. by R. Bonnett, Chemistry Dept., Queen Mary College, London.

Birm-342.

$7830 \pm 520$ only small sample available.

Birm-343.

$8700 \pm 170$

Sample from $0.51 \mathrm{~m}$ depth.

6750 B.C.

General Comment: samples dated to study chemical change of wood with time.

\section{Sharmer Farm series, Fosse Way, Warwickshire}

\section{Birm-344.}

$$
\begin{gathered}
2950 \pm 100 \\
1000 \text { B.C. } \\
\delta C^{13}=-24.4 \%
\end{gathered}
$$

Charcoal from $0.9 \mathrm{~m}$ deep near base of large oval pit, ca. $2.13 \mathrm{~m}$ max width, filled with clay, abundant charcoal, and thousands of heat-cracked stones, in Keuper Marl at Sharmer Farm, Fosse Way, Warwickshire $\left(52^{\circ}\right.$ $15^{\prime} 15^{\prime \prime} \mathrm{N}$ Lat, $1^{\circ}$ 28' 25" W Long, Grid Ref. SP360619). Coll. 1972 and subm. by F. W. S. and N. B. Ellis.

\section{Birm-371.}

$2990 \pm 100$

1040 B.C.

$\delta C^{13}=-23.8 \%$

Charcoal from shallow flat layer of heat-cracked stones ca. $2.4 \mathrm{~m}$ across, adjacent to Birm-344. Coll. 1972 and subm. by F. W. S. and N. B. E.

General Comment (F.W.S.): both structures dated as Late Bronze age and not separable in time, but their function is unknown. 
(a) $1230 \pm 110$ A.D. 720

$\delta C^{13}=-25.0 \%$

Birm-352. Deerhurst, Gloucestershire

(b) $1290 \pm 100$

A.D. 660

$\delta C^{13}=-25.0 \%$

Charcoal from ca. $0.6 \mathrm{~m}$ deep at base of brown sand containing Saxon burials at Deerhurst, Gloucestershire $\left(51^{\circ} 58^{\prime} \mathrm{N}\right.$ Lat, $2^{\circ} 11^{\prime} \mathrm{W}$ Long, Grid Ref. SO871299). Coll. 1971 and subm. by P. A. Rahtz, School Hist., Univ. Birmingham. (a) and (b) are separate measurements in different counters on same methane gas.

\section{Birm-358. Thorne Moor, Yorkshire}

$$
\begin{gathered}
2990 \pm 110 \\
1040 \text { B.c. } \\
\delta C^{13}=-23.9 \%
\end{gathered}
$$

Bark (Pinus) used in timber trackway at ca. $1.7 \mathrm{~m}$ depth in fen peat at Thorne Moor, Yorkshire (53 $37^{\prime} 40^{\prime \prime}$ N Lat, $0^{\circ} 55^{\prime} 10^{\prime \prime}$ W Long, Grid Ref. SE715151). Coll. 1972 and subm. by P. C. B. and H. K. Kenward, Dept. Geol., Univ. Birmingham. Comment (P.C.B.): trackway assoc. with "Landnam" phase. Agrees well with Birm-336 (this list) which dates same forest clearance. Pollen of cereals found in this horizon.

\section{$4160 \pm 120$ \\ Birm-359. Thorne, East Ings, Yorkshire

Wood from ca. $4.7 \mathrm{~m}$ deep at base of dry channel of $\mathrm{R}$. Don in sec. exposed by M18 Motorway cut, NW of Thorne Mere, at Thorne, East Ings, Yorkshire (53 $36^{\prime} 40^{\prime \prime} \mathrm{N}$ Lat, $0^{\circ} 59^{\prime} \mathrm{W}$ Long, Grid Ref. SE671132). Coll. 1971 and subm. by P. C. B. Comment (P.C.B.): assoc. insect fauna implies that area was already largely clear of trees, supported by finds of stone axes. Cf. Birm-328, this list.

Birm-366. Newport, I. of Wight

$$
\begin{gathered}
\text { (a) } 4160 \pm 60 \\
\mathbf{2 2 1 0} \text { в.c. } \\
\delta C^{13}=-25.9 \% \\
\text { (b) } 4210 \pm \mathbf{8 0} \\
\mathbf{2 2 6 0} \text { в.C. } \\
\delta C^{13}=-26.5 \% \\
\text { (c) } 4030 \pm \mathbf{1 8 0} \\
\mathbf{2 0 8 0} \text { B.c. } \\
\delta C^{13}=-27.2 \%
\end{gathered}
$$

Wood (Fraxinus and Alnus), id. at Plant Path Lab., Kew Gdns., London, from peat, 1.83 to $2.09 \mathrm{~m}$ depth under descending sequence of alluvium, brickearth, and thin gravel with large mammal bones and overlying gravel, coombe rock and chalk at Great Pan Farm, Shide Mill, R. Medina, Newport, I. of Wight $\left(50^{\circ} 41^{\prime} 45^{\prime \prime} \mathrm{N}\right.$ Lat, $1^{\circ} 17^{\prime} 15^{\prime \prime} \mathrm{W}$ Long, Grid Ref. SZ505885). Coll. 1972 and subm. by M. L. Shackley, Archaeol. 
Dept., Univ. Southampton. Comment: believed assoc. with a Mousterian industry of Acheulian tradition, proved erroneous as peat gives Holocene date consistent with a Neolithic culture. (a) and (b) are separate samples from same peat layer, (c) is humate extract of (a).

\section{B. Miscellaneous Archaeologic Samples}

\section{Ecuador series, $S$ America}

Fossil human bone fragments enclosed in coarse tuff firmly cemented by calcium carbonate from river terrace, ca. $6.0 \mathrm{~m}$ above river, in $\mathrm{N}$ Ecuador. Coll. 1951 by T. Marrack; subm. by D. M. Davies, Dept. Anatomy, Univ. College, London.

(a) $27,100 \pm 700$ 25,150 B.c.

(b) 35,000 $+2240$

Birm-331. 33,050 B.C.

$$
\text { (c) } \begin{gathered}
\mathbf{2 3 0 0} \pm \mathbf{2 7 0} \\
\mathbf{3 5 0} \text { B.c. } \\
\delta C^{13}=-14.5 \%
\end{gathered}
$$

Outer (a) and inner (b) fraction of aragonite filling bone cavities with some bone calcium carbonate; $\mathrm{CO}_{2}$ evolved with dilute mineral acid. Collagen (c) from bone after aragonite and bone calcium carbonate removed with $10 \%$ acetic acid (petrochemical origin) for 1 week. After further treatment with mineral acid under reduced pressure organic extract treated with dilute alkali for $6 \mathrm{hr}$. Alkali soluble fraction separated, remaining gelatinous collagen washed and dried.

Birm-332.

Aragonite crystals grown inside skull. $\mathrm{CO}_{2}$ evolved with dilute mineral acid under reduced pressure.

\section{Birm-360.}

(a) $22,800 \pm 300$ 20,850 в.c.

(b) $2670 \pm 150$

$$
\begin{gathered}
\mathbf{7 2 0} \text { в.C. } \\
\delta C^{13}=-16.4 \%
\end{gathered}
$$

Separate sample of assoc. human bones of shoulder joint (scapula, humerus, clavicle). Mineral fraction (a) from interstitial aragonite and bone carbonate, evolved with dilute mineral acid under reduced pressure; residual collagen (b) after humate removal with alkali.

General Comment: skeleton was believed very old in view of dates made on encrusting aragonite. Collagen dates disprove this. Difference between collagen and carbonate dates may arise from burial in a tuff, the carbonate largely magmatic in origin. 


\section{Birm-337. Kyrenia, Cyprus}

Hearth material from $1.70 \mathrm{~m}$ deep in Neolithic occupation of site on $\mathrm{N}$ coast of Cyprus at Ajios Epiktitos $11.27 \mathrm{~km} \mathrm{E}$ of Kyrenia, Cyprus $\left(35^{\circ} 20^{\prime}\right.$ N Lat, 33० 25' E Long). Coll. 1971 and subm. by P. S. Gelling, Dept. Ancient Hist. and Archaeol., Univ. Birmingham. Acid pretreatment only. Comment: dates central point in Neolithic occupation of site. Cf. Birm182: $5825 \pm 145$ (R., 1971, v. 13, p. 155), from nearby site.

\section{REFERENCES}

Anderson, E. C., Levi, H., and Tauber, H., 1953, Copenhagen natural radiocarbon measurements I: Science, v. 118, p. 6-9.

Charlesworth, J. K., 1926, The readvance marginal kame-moraine of the South of Scotland and some later stages of retreat: Royal Soc. [Edinburgh] Trans., v. 55, p. 25-50.

Craig, Harmon, 1961, Mass-spectrometer analysis of radiocarbon standards: Radiocarbon, v. 3 , p. $1-3$.

Kendall, P. F., 1902, A system of glacier-lakes in the Cleveland Hills: Geol. soc. London. Quart. Jour., v. 58, p. 471-571.

Mackie, E. W., 1971, Discovery and excavation in Scotland: Council for British Archaeol. (Scottish Regional Group), Edinburgh, p. 7.

McCabe, A. M., 1969, The glacial deposits of the Maguiresbridge area, County Fermanagh, Northern Ireland: Irish Geog., v. 6, p. 63-77.

Mellars, P. A. and Payne, S., 1971, Excavation of two Mesolithic shell middens on the island of Oronsay (Inner Hebrides): Nature, v. 231, no. 5302, p. 397-398.

I'age, N. R., 1972, On the age of the Hoxnian interglacial: Geol. Jour., v. 8, p. 129-142. Pearson, R. G., 1962, The Coleoptera from a late glacial deposit at St. Bees, Cumberland: Jour. Anim. Ecol., v. 31, p. 129-150.

Saunders, G. E., 1968, A fabric analysis of the ground moraine deposits of the Llyn Peninsula of Southwest Caernarvonshire: Geol. Jour., v. 6, p. 105-118.

Sissons, J. B., 1963, The Perth readvance in Central Scotland, Part I: Scot. Geog. Mag., v. 79 , p. $151-163$. v. 80 , p. $28-36$

Synge, F., 1970, The Pleistocene period in Wales, in: Lewis, C. (ed.), The glaciations of Wales and adjoining regions, Longman, London, p. 315-350.

Watson, E., 1972, Pingos of Cardiganshire and the latest ice limit: Nature, v. 236, no. 5346, p. 343-344.

West, R. G., 1956, The Quaternary deposits at Hoxne, Suffolk: Royal Soc. [London] Philos. Trans., ser. B, v. 239, p. 265-356.

Whittow, J. B. and Ball, D., 1970, Northwest Wales, in: Lewis, C. (ed.), The glaciations of Wales and adjoining regions, Longman, London, p. 21-58. 